\title{
Rhodium Nanoparticle-Loaded Carbon Black Electrocatalyst for the Glycerol Oxidation Reaction in Alkaline Medium
}

\author{
Binh Thi Xuan Lam, Masanobu Chiku, Eiji Higuchi, Hiroshi Inoue \\ Department of Applied Chemistry, Graduate School of Engineering, Osaka Prefecture University, Osaka, Japan \\ Email: inoue-h@chem.osakafu-u.ac.jp
}

Received 31 December 2015; accepted 12 February 2016; published 15 February 2016

Copyright (C) 2016 by authors and Scientific Research Publishing Inc.

This work is licensed under the Creative Commons Attribution International License (CC BY). http://creativecommons.org/licenses/by/4.0/

(c) () Open Access

\begin{abstract}
Rhodium nanoparticle-loaded carbon black ( $\mathrm{Rh} / \mathrm{CB}$ ) was prepared by a wet method, and its activity and durability for glycerol oxidation reaction (GOR) in alkaline medium were compared with $\mathrm{Pt}, \mathrm{Pd}$ and $\mathrm{Au}$ nanoparticle-loaded $\mathrm{CB}$ (Pt/CB, Pd/CB and Au/CB). In the cyclic voltammogram of the $\mathrm{Rh} / \mathrm{CB}$ electrode, the redox waves due to hydrogen adsorption/desorption and the surface $\mathrm{OH}$ monolayer formation/reduction were observed at more negative potentials than the $\mathrm{Pt} / \mathrm{CB}$ and $\mathrm{Pd} / \mathrm{CB}$ electrodes. The onset and peak potentials of the GOR current densities for the Rh/CB electrode were ca. -0.55 and $-0.30 \mathrm{~V}$ vs. $\mathrm{Hg} / \mathrm{HgO}$, respectively, which were 0.10 and $0.20 \mathrm{~V}$ more negative than the Pt/CB electrode whose GOR activity was the best, indicating that $\mathrm{Rh}$ was a fascinating metal for reducing the overpotential for GOR. In the electrostatic electrolysis with the Rh/CB and $\mathrm{Pt} / \mathrm{CB}$ electrodes, the decrease in the GOR current density in the former with time was suppressed compared to that in the latter, suggesting that the tolerance to poisoning for the $\mathrm{Rh} / \mathrm{CB}$ electrode was superior to that for the Pt/CB electrode.
\end{abstract}

\section{Keywords}

Glycerol Oxidation Reaction, Direct Glycerol Fuel Cell, Rhodium, Nanoparticle

\section{Introduction}

Biodiesel fuel (BDF) attracts attention as a carbon-neutral fuel as well as bioethanol. As the production of BDF increases, the production of the glycerol byproduct is also increasing. Glycerol is used for pharmaceuticals, cosmetics, food additives, synthetic raw materials, and antifreeze. However, it is important to develop new uses 
for glycerol to cope with the mass production of BDF. Direct alcohol fuel cells (DAFCs), in which methanol and ethanol are used as fuels, have attracted considerable interest because they have a high energy density and advantages of easy handling, storage, and transportation compared with pure hydrogen [1]-[4]. The use of glycerol as a fuel for DAFCs is promising, because direct glycerol fuel cells are expected to produce electricity with a low environmental load and to be energy-efficient.

So far, pure metal electrocatalysts such as Pt, Au and Pd [5]-[11] have been applied for GOR. In general, active catalysts have the more negative onset potential $\left(E_{\text {onset }}\right)$ and peak potential $\left(E_{\mathrm{p}}\right)$ of the GOR current, and the higher peak GOR current density per unit electrochemical surface area (ECSA) $\left(j_{\mathrm{p}}\right)$. Pt has the most negative $E_{\text {onset }}$ among pure metal electrocatalysts reported previously, whereas Au has the highest $j_{\mathrm{p}}$. However, $\mathrm{Pt}$ is insufficient for the $E_{\mathrm{p}}$ and $j_{\mathrm{p}}$, whereas Au is inferior to Pt in the $E_{\text {onset }}$ and $E_{\mathrm{p}}$.

Ethanol, ethylene glycol and glycerol have one or more C-C bonds. For completely oxidizing the alcohol molecules to $\mathrm{CO}_{2}$, the C-C bonds need to be broken in addition to the oxidation of hydroxy group. So active catalysts to rapidly break the C-C bonds are required. Rhodium has been reported to break the C-C bond of an ethanol molecule to enhance the selective production of $\mathrm{CO}_{2}$ [12], and Pt-Rh-Sn ternary catalysts succeeded in facilitating the C-C bond cleavage [13] [14]. In this way Rh is a promising metal to catalyze the C-C bond cleavage of a glycerol molecule and facilitate GOR. However, to our knowledge, the catalysis of pure Rh and Rh-based alloys for GOR has scarcely been investigated. There are many synthetic approaches of metal nanoparticle catalysts such as the hydrothermal method, sol-gel process, templating method, and polyol synthesis [15]. In these wet methods, stabilizers are often required to suppress the aggregation of nanoparticles and control the particle size distribution; however, they must be removed by heat treatment and anodic oxidation [16] [17] to enhance the utilization of the catalyst. It is desirable to avoid the additional purification process to reduce costs and energy use. We also have developed a wet method to prepare metal nanoparticle-loaded carbon black (CB), in which rhodium chloride was reduced by $\mathrm{KBH}_{4}$ in presence of tetraoctylammonium bromide $\left(\mathrm{N}(\mathrm{Oct})_{4} \mathrm{Br}\right)$ as stabilizer [18]. It is noteworthy that the stabilizer was easily removed by washing [18], which can overcome the above-mentioned problem. Therefore, in this study, pure Rh nanoparticle-loaded carbon black (Rh/CB) catalyst was prepared by our wet method at room temperature, and in order to investigate the intrinsic catalysis of Rh nanoparticle catalyst for GOR in an alkaline medium. Its catalytic activity and stability for GOR were evaluated, and compared with the other metal catalysts.

\section{Experimental}

\subsection{Reagents}

Rhodium chloride trihydrate $\left(\mathrm{RhCl}_{3} \cdot 3 \mathrm{H}_{2} \mathrm{O}-\right.$ Wako, Japan), platinum chloride $\left(\mathrm{PtCl}_{2}\right.$-Wako, Japan), potassium chloroaurate ( $\mathrm{KAuCl}_{4}$-Sigma-Aldrich, USA) and palladium acetate $\left(\mathrm{Pd}\left(\mathrm{CH}_{3} \mathrm{COO}\right)_{2}\right.$-Wako, Japan) as precursors to prepare $\mathrm{Rh}, \mathrm{Pt}, \mathrm{Au}$ and $\mathrm{Pd}$ nanoparticles, respectively, were used as received. $\mathrm{N}(\mathrm{Oct})_{4} \mathrm{Br}$ (Wako, Japan) as stabilizer, potassium tetrahydroborate $\left(\mathrm{KBH}_{4}\right.$-Sigma-Aldrich, USA) as reducing agent, Ketjenblack (Lion, Japan) as carbon black (CB) were used as received. All other reagents were purchased from Wako, Japan, and used as received.

\subsection{Preparation and Characterization of Nanoparticle-Loaded Carbon Black}

The $\mathrm{Rh} / \mathrm{CB}$ was prepared according to ref. [18]. Briefly, a solution of $\mathrm{KBH}_{4}(4 \mathrm{mmol})$ in $\mathrm{H}_{2} \mathrm{O}(1.5 \mathrm{~mL})$ was slowly added dropwise to a vigorously stirred solution containing $\mathrm{RhCl}_{3} \cdot 3 \mathrm{H}_{2} \mathrm{O}(1 \mathrm{mmol})$ and $\mathrm{N}(\mathrm{Oct})_{4} \mathrm{Br}(4 \mathrm{mmol})$ in tetrahydrofuran (THF, $150 \mathrm{~mL}$ ) at $30^{\circ} \mathrm{C}$ in an $\mathrm{Ar}$ atmosphere. The reaction mixture was stirred for $30 \mathrm{~min}$, resulting in a blackcolloidal suspension. The suspended solid was isolated by suction filtration in air and washed with excess $\mathrm{H}_{2} \mathrm{O}$, acetone, and ethanol at room temperature, yielding a black waxy solid. The black solid was redispersed in ethanol. Ketjen black $(67 \mathrm{mg}$ ) was added in the dispersion and sonicated for $10 \mathrm{~min}$. After suction filtration, the residue was redispersed in aqueous $0.1 \mathrm{M} \mathrm{HClO}_{4}(300 \mathrm{~mL})$ and then sonicated for $10 \mathrm{~min}$. After suction filtration, the residue was washed with excess $\mathrm{H}_{2} \mathrm{O}$, acetone, and ethanol at room temperature. The $\mathrm{Pt} / \mathrm{CB}, \mathrm{Au} / \mathrm{CB}$ and $\mathrm{Pd} / \mathrm{CB}$ for comparison were also prepared in the same procedure as the $\mathrm{Rh} / \mathrm{CB}$ by using 1 mmol of $\mathrm{PtCl}_{2}, \mathrm{KAuCl}_{4}$ and $\mathrm{Pd}\left(\mathrm{CH}_{3} \mathrm{COO}\right)_{2}$, respectively.

Thermogravimetry (TG) was performed in air (Thermo plus TG8120, Rigaku) by heating from room temperature to $800^{\circ} \mathrm{C}$ at a rate of $1 \mathrm{Kmin}^{-1}$. From TG, the loading in each catalyst was evaluated as $52 \mathrm{wt} \%$ for $\mathrm{Rh} / \mathrm{CB}$, $50 \mathrm{wt} \%$ for $\mathrm{Pt} / \mathrm{CB}, 58 \mathrm{wt} \%$ for $\mathrm{Pd} / \mathrm{CB}$ and $58 \mathrm{wt} \%$ for Au/CB. The structure and average size of Rh, Pt, Au and 
Pd nanoparticles for the $\mathrm{Rh} / \mathrm{CB}, \mathrm{Pt} / \mathrm{CB}, \mathrm{Au} / \mathrm{CB}$ and $\mathrm{Pd} / \mathrm{CB}$ were determined by X-ray diffractometry (XRD, XRD-6100, Shimadzu) equipped with a CuK $\alpha$ source $\left(\lambda=0.1541 \mathrm{~nm}, 40 \mathrm{kV}, 30 \mathrm{~mA}, 1 \mathrm{Kmin}^{-1}\right)$ and by electron dispersive X-ray (EDX) spectroscopy, respectively. The chemical state of Rh, Pt, Au or Pd was measured by X-ray photoelectron spectroscopy (XPS, ESCA-3200, Shimadzu). The X-ray source was MgK $\alpha$ with $1253.6 \mathrm{eV}$ operating at $10 \mathrm{kV}$ and $20 \mathrm{~mA}$. The base pressure of the system was $1.3 \times 10^{-7} \mathrm{~Pa}$.

\subsection{Preparation and Electrochemical Characterization of Nanoparticle-Loaded Carbon Black Electrodes}

The modification of each catalyst on a glassy carbon (GC) substrate $(5 \mathrm{~mm} \phi)$ was performed according to our previous paper [16]. The catalyst loading per unit geometric surface area of GC was adjusted to $w_{\mathrm{CB}}=4.9$ $\mu \mathrm{g} \cdot \mathrm{cm}^{-2}$ ( $w_{\mathrm{CB}}$ : amount of CB loaded on GC), whereas the amount of each catalyst loaded on the GC was 12.8 $\mu \mathrm{g} \cdot \mathrm{cm}^{-2}$. A $0.05 \mathrm{wt} \%$ Nafion solution (Aldrich) in ethanol $(10 \mu \mathrm{L})$ was cast on the dried catalyst layer, and then dried in air at $120^{\circ} \mathrm{C}$ for $1 \mathrm{~h}$, resulting in a catalyst electrode thinly coated with $0.1-\mu \mathrm{m}$-thick Nafion film. A Pt plate and an $\mathrm{Hg} / \mathrm{HgO} / \mathrm{KOH}$ electrode were used as the counter and reference electrodes, respectively. The GOR activity and stability of each electrode were evaluated in $1 \mathrm{M} \mathrm{KOH}$ solution containing $0.5 \mathrm{M}$ glycerol at room temperature by cyclic voltammetry (ALS730C, BAS) and potentiostatic electrolysis (ALS730C, BAS).

To evaluate the ECSA of each metal nanoparticle, cyclic voltammogram (CV) was measured in $1 \mathrm{M} \mathrm{KOH}$ solution at a sweep rate of $20 \mathrm{mV} \cdot \mathrm{s}^{-1}$. The ECSA of Pt and Rh nanoparticles loaded on CB was evaluated as 0.36 and $0.79 \mathrm{~cm}^{2}$ from the electric charge for the desorption of adsorbed hydrogen, assuming a charge density of 210 and $221 \mu \mathrm{C} \cdot \mathrm{cm}^{-2}$ for polycrystalline Pt [19] and Rh [20], respectively. The ECSA of Pd and Au was evaluated as 0.36 and $0.072 \mathrm{~cm}^{2}$ from the electric charge for the reduction of the PdO and AuO monolayers, assuming a charge density of 424 and $493 \mu \mathrm{C} \cdot \mathrm{cm}^{-2}$ for polycrystalline Pd and Au, respectively [21].

\section{Results and Discussion}

\subsection{Rhodium, Platinum, Palladium and Gold Nanoparticles-Loaded Carbon Black Catalyst Structure}

Figure 1(a) shows XRD patterns for Rh/CB, Pt/CB, Pd/CB, and Au/CB. Each XRD pattern contained a small broad diffraction peak at $2 \theta=20^{\circ}-25^{\circ}$, which was assigned to the (002) plane of CB with a hexagonal structure
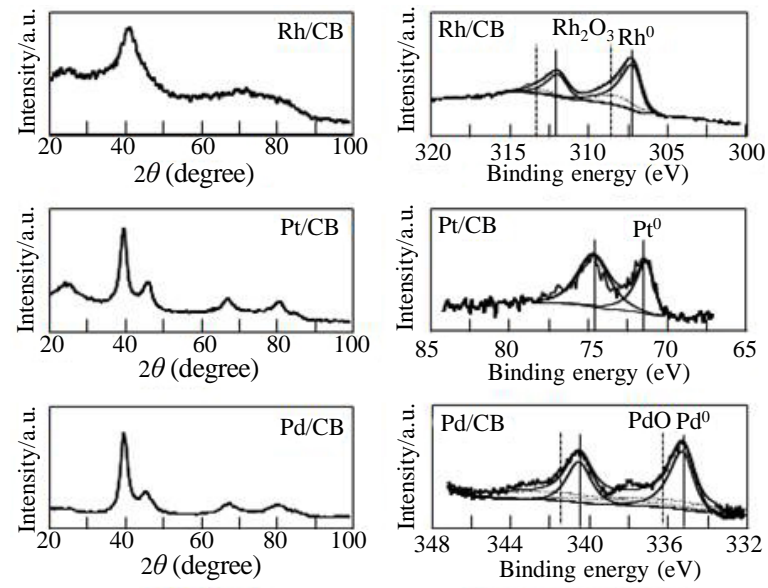

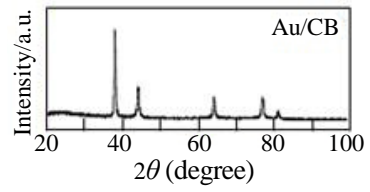

(a) XRD

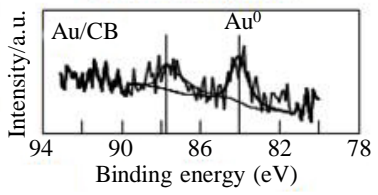

(b) XPS

Figure 1. (a) X-ray diffraction patterns and (b) Rh3d, Pt4f, $\mathrm{Pd} 3 \mathrm{~d}$ and Au4f core level spectra for Rh/CB, Pt/CB, Pd/CB and $\mathrm{Au} / \mathrm{CB}$. 
[16]. Each catalyst had the largest diffraction peak around $38^{\circ}-41^{\circ}$ for the (111) plane of the face-centered cubic (fcc) structure [22]. For Pt/CB, Pd/CB and Au/CB, the (200), (220) and (311) peaks, which were also characteristic of the fcc structure [10] [23], were observed in Figure 1(a), whereas for Rh/CB the diffraction peaks were not distinctly observed. The crystallite size of each metal nanoparticle loaded on CB was estimated by inserting the full width at half maximum of the (111) peak in each XRD pattern of Figure 1(a) into Scherrer's equation. The average crystallite size was $1.6 \mathrm{~nm}$ for $\mathrm{Rh} / \mathrm{CB}, 3.8 \mathrm{~nm}$ for $\mathrm{Pt} / \mathrm{CB}, 3.6 \mathrm{~nm}$ for $\mathrm{Pd} / \mathrm{CB}$ and $21 \mathrm{~nm}$ for $\mathrm{Au} / \mathrm{CB}$.

XPS analyses for all catalysts did not show any peaks in N1s, and Br3d core level, suggesting that in all cases the $\mathrm{N}(\mathrm{Oct})_{4} \mathrm{Br}$ stabilizer was completely removed by thoroughly washing with $\mathrm{H}_{2} \mathrm{O}$, ethanol and acetone and $\mathrm{HClO}_{4}$ solution. The Rh3d, Pt4f, Pd3d and Au4f core level spectra for Rh/CB, Pt/CB, Pd/CB and Au/CB are shown in Figure 1(b), respectively. For $\mathrm{Rh} / \mathrm{CB}$, the Rh3d spectrum contained doublets assigned to the $3 \mathrm{~d}_{5 / 2}$ and $3 \mathrm{~d}_{3 / 2}$ peaks of metallic $\mathrm{Rh}$ and small shoulders assigned to $\mathrm{Rh}_{2} \mathrm{O}_{3}$ at higher binding energies [24]. For the other catalysts, each core level spectrum contained doublets assigned to metallic Pt, Pd or Au. For Pd/CB, weak doublets assigned to PdO [25] were also detected.

\subsection{Electrochemical Properties and Glycerol Oxidation Reaction Activity for Rhodium, Platinum, Palladium and Gold Nanoparticles-Loaded Carbon Black Catalyst}

Figure 2(a) shows the CVs of Nafion-coated $\mathrm{Rh} / \mathrm{CB}, \mathrm{Pt} / \mathrm{CB}, \mathrm{Pd} / \mathrm{CB}$ and $\mathrm{Au} / \mathrm{CB}$ electrodes in an Ar-saturated 1 $\mathrm{M} \mathrm{KOH}$ solution. The $\mathrm{CVs}$ of the $\mathrm{Pt} / \mathrm{CB}, \mathrm{Pd} / \mathrm{CB}$ and $\mathrm{Au} / \mathrm{CB}$ electrodes were consistent with the previous result [10]. For the Pt/CB electrode, two couples of redox waves due to hydrogen adsorption/desorption were observed in the potential range between -0.75 and $-0.5 \mathrm{~V}$ vs. $\mathrm{Hg} / \mathrm{HgO}$ [10], whereas the oxidation current due to the adsorbed $\mathrm{OH}\left(\mathrm{Pt}-\mathrm{OH}_{\mathrm{ad}}\right)$ formation began to flow around $-0.45 \mathrm{~V}$ in the forward sweep and its reduction current began to flow around $0 \mathrm{~V}$ in the backward sweep. In the $\mathrm{CV}$ of the $\mathrm{Pd} / \mathrm{CB}$ electrode, the redox waves owing to hydrogen adsorption (absorption)/desorption were observed in the potential range below $-0.4 \mathrm{~V}$, whereas the oxidation current caused by the surface $\mathrm{Pd}-\mathrm{OH}_{\mathrm{ad}}$ formation [8] [26] began to flow around $-0.15 \mathrm{~V}$ in the forward sweep and its reduction current had a peak around $-0.18 \mathrm{~V}$ in the backward sweep. In the $\mathrm{CV}$ of the $\mathrm{Au} / \mathrm{CB}$ electrode, the gold oxide reduction peak was observed at ca. $0.13 \mathrm{~V}$ in $\mathrm{Au} / \mathrm{CB}$ [11]. On the other hand, in the CV of the $\mathrm{Rh} / \mathrm{CB}$ electrode, the redox waves due to hydrogen adsorption/desorption were observed in the potential range less than $-0.6 \mathrm{~V}$ vs. $\mathrm{Hg} / \mathrm{HgO}$. And the oxidation current due to the surface $\mathrm{Rh}^{-} \mathrm{OH}_{\mathrm{ad}}$ formation began to flow around $-0.55 \mathrm{~V}$ in the forward sweep and its reduction current had a peak around $-0.47 \mathrm{~V}$ in the backward sweep, indicating that the formation and reduction of $\mathrm{Rh}-\mathrm{OH}_{\mathrm{ad}}$ occurred at more negative potential than those of $\mathrm{Pt}-\mathrm{OH}_{\mathrm{ad}}$.
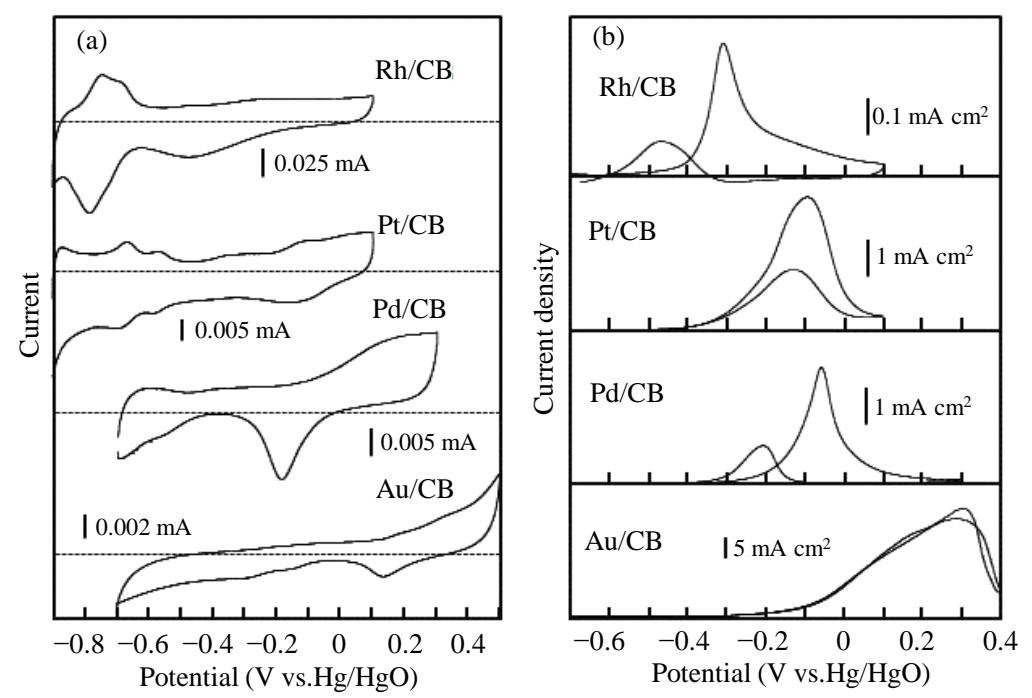

Figure 2. CVs in an Ar-saturated $1 \mathrm{M} \mathrm{KOH}$ solution (a) without and (b) with $0.5 \mathrm{M}$ glycerol for Nafion-coated Rh/CB, Pt/CB, Pd/CB and Au/CB electrodes. Sweep rate $=20 \mathrm{mV} \mathrm{s}^{-1}$. 
Figure 2(b) shows CVs of Nafion-coated Rh/CB, Pt/CB, Pd/CB and Au/CB electrodes in an Ar-saturated 1 $\mathrm{M} \mathrm{KOH}$ solution containing $0.5 \mathrm{M}$ glycerol. All current densities in each voltammogram are represented as current per unit ECSA of each metal. Among the Pt/CB, $\mathrm{Pd} / \mathrm{CB}$ and $\mathrm{Au} / \mathrm{CB}$ electrodes, the onset and peak potentials of GOR at the Pt/CB electrode (ca. $-0.45 \mathrm{~V}$ and $-0.1 \mathrm{~V}$ ) were more negative than those at the Pd/CB electrode (ca. $-0.3 \mathrm{~V}$ and $-0.05 \mathrm{~V}$ ) and the $\mathrm{Au} / \mathrm{CB}$ electrode (ca. $-0.25 \mathrm{~V}$ and $0.3 \mathrm{~V}$ ). In terms of the GOR current density, the $\mathrm{Au} / \mathrm{CB}$ electrode was greater than the $\mathrm{Pt} / \mathrm{CB}$ and $\mathrm{Pd} / \mathrm{CB}$ electrodes. These trends were in agreement with the previous literatures [8]-[10]. On the other hand, the onset and peak potentials of the GOR current densities for the $\mathrm{Rh} / \mathrm{CB}$ electrode were ca. -0.55 and $-0.30 \mathrm{~V}$, respectively, which were 0.10 and $0.20 \mathrm{~V}$ more negative than the $\mathrm{Pt} / \mathrm{CB}$ electrode. From the comparison in the onset potential between the $\mathrm{Rh} / \mathrm{CB}$ and $\mathrm{Pt} / \mathrm{CB}$ electrodes, the $\mathrm{Rh} / \mathrm{CB}$ electrode was $0.10 \mathrm{~V}$ smaller in overpotential for GOR than the Pt/CB electrode whose GOR activity was the best, indicating that GOR occurred more easily on the Rh surface. The onset potential of GOR at the $\mathrm{Rh} / \mathrm{CB}$ electrode was close to that of oxide formation as well as the $\mathrm{Pt} / \mathrm{CB}$ and $\mathrm{Pd} / \mathrm{CB}$ electrodes, suggesting that the GOR on the Rh surface followed bi-functional mechanism [27] [28]. However, the GOR current density at the Rh electrode was much smaller than that at the Pt electrode. In the ethanol oxidation reaction, $\mathrm{Rh}$ was not catalytically active, but PtRh binary electrocatalyst was more active than Pt because Rh facilitated the breaking of the C-C bond to improve the catalytic activity of Pt [29]. Therefore, the GOR current density will be improved by the alloying of Rh with the second elements such as Pt, Ag and $\mathrm{Ni}$.

The oxidation current in the backward sweep would scarcely appear if the poisoning carbonaceous intermediates were completely removed in the forward sweep, so the ratio of peak current densities in the forward sweep $\left(i_{f}\right)$ and backward sweep $\left(i_{b}\right)$ is a measure of how clean the catalyst surface is or how high the tolerance to poisoning species is [30]. The $i_{b} / i_{\mathrm{f}}$ ratios for the $\mathrm{Rh} / \mathrm{CB}, \mathrm{Pt} / \mathrm{CB}, \mathrm{Pd} / \mathrm{CB}$ and $\mathrm{Au} / \mathrm{CB}$ electrodes were evaluated to be $0.30,0.42,0.32$ and 0.90 , respectively. The $i_{b} / i_{\text {f }}$ ratio for the $\mathrm{Rh} / \mathrm{CB}$ electrode was smaller than the $\mathrm{Pt} / \mathrm{CB}$ and $\mathrm{Au} / \mathrm{CB}$ electrodes and comparable to the $\mathrm{Pd} / \mathrm{CB}$ electrode, suggesting that $\mathrm{Rh} / \mathrm{CB}$ as well as $\mathrm{Pd} / \mathrm{CB}$ was tolerant to poisoning species.

Figure 3 shows time courses of oxidation current density at various potentials in an Ar-saturated $1.0 \mathrm{M} \mathrm{KOH}$ solution containing $0.5 \mathrm{M}$ glycerol for the $\mathrm{Rh} / \mathrm{CB}, \mathrm{Pt} / \mathrm{CB}, \mathrm{Pd} / \mathrm{CB}$ and $\mathrm{Au} / \mathrm{CB}$ electrodes. For the $\mathrm{Rh} / \mathrm{CB}$ electrode, the GOR current density at $-0.35 \mathrm{~V}$, which was more negative than the peak potential of GOR $(-0.30 \mathrm{~V})$, was larger than that at $-0.25 \mathrm{~V}$, which was more positive than the peak potential, even after $60 \mathrm{~min}$. In contrast, for the Pt/CB electrode the oxidation current densities at -0.1 and $0 \mathrm{~V}$, which were much more positive potentials than those for the Rh/CB electrode, significantly decreased with time. The decrease in the oxidation current
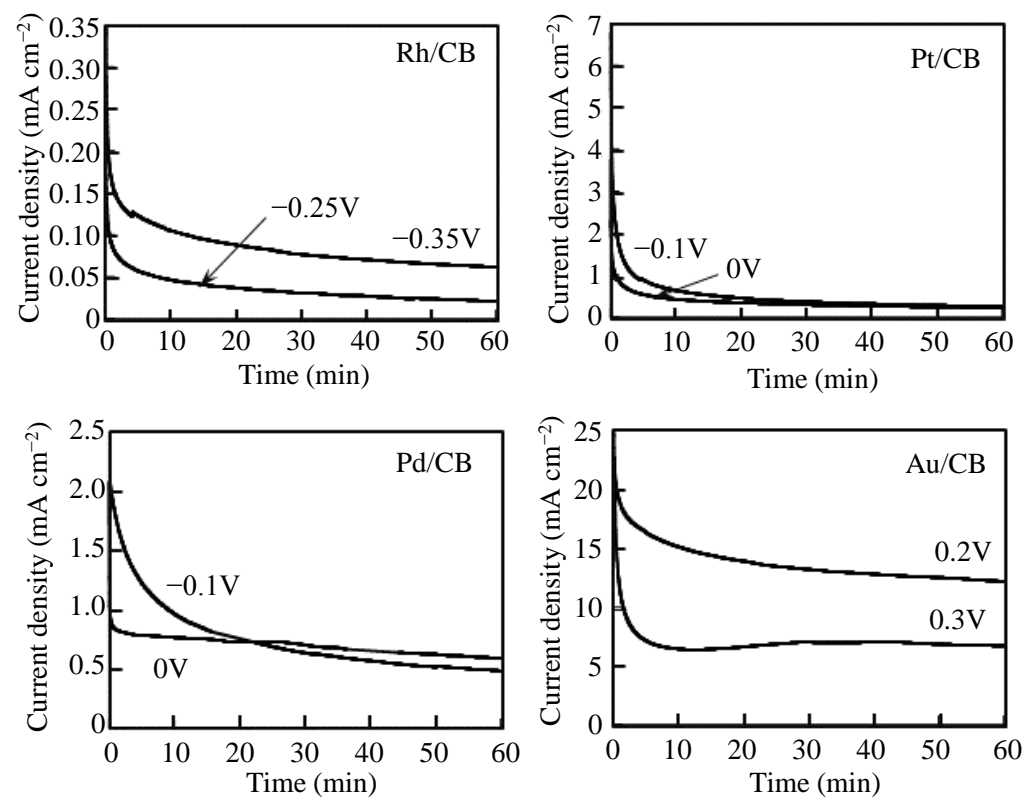

Figure 3. Time courses of the oxidation current density in electrostatic electrolysis at various potentials for Nafion-coated $\mathrm{Rh} / \mathrm{CB}, \mathrm{Pt} / \mathrm{CB}, \mathrm{Pd} / \mathrm{CB}$ and $\mathrm{Au} / \mathrm{CB}$ electrodes. Electrolyte: $1 \mathrm{M} \mathrm{KOH}$ containing $0.5 \mathrm{M}$ glycerol. 
density is closely related to the deterioration of catalyst, so the ratio of oxidation current density at 60 and 5 min $\left(i_{60} / i_{5}\right)$ can be evaluated as an indicator of the catalyst deterioration. The $i_{60} / i_{5}$ values at $-0.35 \mathrm{~V}$ for the Rh/CB electrode and at $-0.1 \mathrm{~V}$ for the Pt electrode were 0.50 and 0.29 , respectively, indicating that the deterioration of $\mathrm{Rh} / \mathrm{CB}$ was suppressed more effectively. It is concluded that $\mathrm{Rh} / \mathrm{CB}$ was more tolerant to poisoning species than $\mathrm{Pt} / \mathrm{CB}$.

\section{Conclusion}

$\mathrm{Rh} / \mathrm{CB}$ was prepared by a wet method at room temperature. The $\mathrm{N}(\mathrm{Oct})_{4} \mathrm{Br}$ stabilizer was easily removed by thorough washing. In the $\mathrm{CV}$ of the $\mathrm{Rh} / \mathrm{CB}$ electrode, the redox waves due to hydrogen adsorption/desorption and the surface $\mathrm{OH}$ monolayer formation/reduction were observed at more negative potentials than the $\mathrm{Pt} / \mathrm{CB}$ and $\mathrm{Pd} / \mathrm{CB}$ electrodes. The onset and peak potentials of GOR current densities for the $\mathrm{Rh} / \mathrm{CB}$ electrode were ca. -0.55 and $-0.30 \mathrm{~V}$ vs. $\mathrm{Hg} / \mathrm{HgO}$, respectively, which were 0.10 and $0.20 \mathrm{~V}$ more negative than the $\mathrm{Pt} / \mathrm{CB}$ electrode whose GOR activity was the best, indicating that the Rh electrode was fascinating metal for reducing the overpotential for GOR. The GOR current density at $-0.35 \mathrm{~V}$ was larger than that at $-0.25 \mathrm{~V}$ even after 60 min, whereas the Pt/CB electrode exhibited a rapid decrease in oxidation current density at -0.1 and $0 \mathrm{~V}$, suggesting that $\mathrm{Rh} / \mathrm{CB}$ had a higher tolerance to poisoning species than Pt/CB. The GOR current density for the Rh electrode was smaller than that for the Pt electrode, but it will be improved by the alloying of Rh with the second elements such as Pt, Ag and Ni.

\section{Acknowledgements}

This work was partially supported by JSPS KAKENHI Grant Number 15 H04162.

\section{References}

[1] Kakati, N., Maiti, J., Lee, S.H., Viswanathan, B. and Yoon, Y.S. (2014) Anode Catalysts for Direct Methanol Fuel Cells in Acidic Media: Do We Have Any Alternative for Pt or Pt-Ru? Chemical Review, 114, 12397-12429. http://dx.doi.org/10.1021/cr400389f

[2] Antolini, E. (2007) Catalysts for Direct Ethanol Fuel Cells. Journal of Power Sources, 170, 1-12. http://dx.doi.org/10.1016/j.jpowsour.2007.04.009

[3] Lamy, C., Rousseau, S., Belgsir, E.M., Countanceau, C. and Léger, J. (2004) Recent Progress in the Direct Ethanol Fuel Cell: Development of New Platinum-Tin Electrocatalysts. Electrochimica Acta, 49, 3901-3908. http://dx.doi.org/10.1016/j.electacta.2004.01.078

[4] Behr, A., Eilting, J., Irawadi, K., Leschinski, J. and Lindner, F. (2008) Improved Utilisation of Renewable Resources: New Important Derivatives of Glycerol. Green Chemistry, 10, 13-30. http://dx.doi.org/10.1039/B710561D

[5] Shen, P.K. and Xu, C. (2006) Alcohol Oxidation on Nanocrystalline Oxide Pd/C Promoted Electrocatalysts. Electrochemistry Communications, 8, 184-188. http://dx.doi.org/10.1016/j.elecom.2005.11.013

[6] Simões, M., Baranton, S. and Coutanceau, C. (2010) Electro-Oxidation of Glycerol at Pd Based Nano-Catalysts for an Application in Alkaline Fuel Cells for Chemicals and Energy Cogeneration. Applied Catalysis B: Environmental, 93, 354-362. http://dx.doi.org/10.1016/j.apcatb.2009.10.008

[7] Kwon, Y. and Koper, M.T.M. (2010) Combining Voltammetry with HPLC: Application to Electro-Oxidation of Glycerol. Analytical Chemistry, 82, 5420-5424. http://dx.doi.org/10.1021/ac101058t

[8] Habibi, E. and Razmi, H. (2012) Glycerol Electrooxidation on Pd, Pt and Au Nanoparticles Supported on Carbon Ceramic Electrode in Alkaline Media. International Journal of Hydrogen Energy, 37, 16800-16809. http://dx.doi.org/10.1016/j.ijhydene.2012.08.127

[9] Zhang, J., Liang, Y., Li, N., Li, Z., Xu, C. and Jiang, S.P. (2012) A Remarkable Activity of Glycerol Electrooxidation on Gold in Alkaline Medium. Electrochimica Acta, 59, 156-159. http://dx.doi.org/10.1016/j.electacta.2011.10.048

[10] Zhang, Z., Xin, L., Qi, J., Chadderdon, D.J. and Li, W. (2013) Supported Pt, Pd and Au Nanoparticle Anode Catalysts for Anion-Exchange Membrane Fuel Cells with Glycerol and Crude Glycerol Fuels. Applied Catalysis B: Environmental, 136, 29-39. http://dx.doi.org/10.1016/j.apcatb.2013.01.045

[11] Marshall, A.T., Golovko, V. and Padayachee, D. (2015) Influence of Gold Nanoparticle Loading in Au/C on the Activity towards Electrocatalytic Glycerol Oxidation. Electrochimica Acta, 153, 370-378. http://dx.doi.org/10.1016/j.electacta.2014.11.186

[12] De Tacconi, N.R., Lezna, R.O., Beden, B., Hahn, F. and Lamy, C. (1994) In-Situ FTIR Study of the Electrocatalytic 
Oxidation of Ethanol at Iridium and Rhodium Electrodes. Journal of Electroanalytical Chemistry, 379, 329-337. http://dx.doi.org/10.1016/0022-0728(94)87155-8

[13] Kowal, A., Li, M., Shao, M., Sasaki, K., Vukmirovic, M.B., Zhang, J., Marinkovic, N.S., Liu, P., Frenkel, A.I. and Adzic, R.R. (2009) Ternary Pt/Rh/SnO 2 Electrocatalysts for Oxidizing Ethanol to $\mathrm{CO}_{2}$. Nature Materials, 8, 325-330. http://dx.doi.org/10.1038/nmat2359

[14] Silva-Junior, L.C., Maia, G., Passos, R.R., de Souza, E.A., Camara, G.A. and Giz, M.J. (2013) Analysis of the Selectivity of PtRh/C and PtRhSn/C to the Formation of $\mathrm{CO}_{2}$ during Ethanol Electrooxidation. Electrochimica Acta, 112, 612-619. http://dx.doi.org/10.1016/j.electacta.2013.09.030

[15] Na, K., Zhang, Q. and Somorjai, G.A. (2014) Colloidal Metal Nanocatalysts: Synthesis, Characterization, and Catalytic Applications. Journal of Cluster Science, 25, 83-114. http://dx.doi.org/10.1007/s10876-013-0636-6

[16] Higuchi, E., Miyata, K., Takase, T. and Inoue, H. (2011) Ethanol Oxidation Reaction Activity of Highly Dispersed $\mathrm{Pt} / \mathrm{SnO}_{2}$ Double Nanoparticles on Carbon Black. Journal of Power Sources, 196, 1730-1737. http://dx.doi.org/10.1016/j.jpowsour.2010.10.008

[17] Higuchi, E., Okada, K., Chiku, M. and Inoue, H. (2015) Electrocatalytic Activity for Oxygen Reduction Reaction of $\mathrm{Pt} / \mathrm{Au} / \mathrm{CB}$ Catalyst with Different Core Sizes. Electrochimica Acta, 179, 100-107. http://dx.doi.org/10.1016/j.electacta.2015.03.079

[18] Lam, B.T.X., Chiku, M., Higuchi, E. and Inoue, H. (2015) Preparation of PdAg and PdAu Nanoparticle-Loaded Carbon Blackcatalysts and Their Electrocatalytic Activity for the Glycerol Oxidationreaction in Alkaline Medium. Journal of Power Sources, 297, 149-157. http://dx.doi.org/10.1016/j.jpowsour.2015.07.086

[19] Trasatti, S. and Petrii, O.A. (1991) Real Surface Area Measurements in Electrochemistry. Pure \& Applied Chemistry, 63, 711-734. http://dx.doi.org/10.1351/pac199163050711

[20] Lukaszewski, M., Siwek, H. and Czerwinski, A. (2007) Electrochemical Behavior of Thin Polycrystalline Rhodium Layers Studied by Cyclic Voltammetry and Quartz Crystal Microbalance. Electrochimica Acta, 52, 4560-4565. http://dx.doi.org/10.1016/j.electacta.2006.12.066

[21] Simões, M., Baranton, S. and Coutanceau, C. (2009) Electrooxidation of Sodium Borohydride at $\mathrm{Pd}, \mathrm{Au}$, and $\mathrm{Pd}_{x} \mathrm{Au}_{1-x}$ Carbon-Supported Nanocatalysts. Journal of Physical Chemistry C, 113, 13369-13376. http://dx.doi.org/10.1021/jp902741z

[22] Shen, S.Y., Zhao, T.S. and Xu, J.B. (2010) Carbon Supported PtRh Catalysts for Ethanol Oxidation in Alkaline Direct Ethanol Fuel Cell. International Journal of Hydrogen Energy, 35, 12911-12917. http://dx.doi.org/10.1016/j.ijhydene.2010.08.107

[23] Li, G., Jiang, L., Jiang, Q., Wang, S. and Sun, G. (2011) Preparation and Characterization of $\mathrm{Pd}_{x} \mathrm{Ag}_{y} / \mathrm{C}$ Electrocatalysts for Ethanol Electrooxidation Reaction in Alkaline Media. Electrochimica Acta, 56, 7703-7711. http://dx.doi.org/10.1016/j.electacta.2011.06.036

[24] Assumpcao, M.H.M.T., Piasentin, R.M., Hammer, P., De Souza, R.F.B., Buzzo, G.S., Santos, M.C., Spinace, E.V., Neto, A.O. and Silva, J.C.M. (2015) Oxidation of Ammonia Using PtRh/C Electrocatalysts: Fuel Cell and Electrochemical Evaluation. Applied Catalysis B: Environmental, 174-175, 136-144. http://dx.doi.org/10.1016/j.apcatb.2015.02.021

[25] Moulder, J.F., Stickle, W.F., Sobol, P.E. and Bomben, K.D. (1995) Handbook of X-Ray Photoelectron Spectroscopy. Physical Electronics, Inc., Chanhassen.

[26] Burke, L.D. and Casey, J.K. (1993) The Electrocatalytic Behaviour of Palladium in Acid and Base. Journal of Applied Electrochemistry, 23, 573-582. http://dx.doi.org/10.1007/BF00721948

[27] Watanabe, M. and Motoo, S. (1975) Electrocatalysis by Ad-Atoms: Part II. Enhancement of the Oxidation of Methanol on Platinum by Ruthenium Ad-Atoms. Journal of Electroanalytical Chemistry, 60, 267-273. http://dx.doi.org/10.1016/S0022-0728(75)80261-0

[28] Li, H., Sun, G., Cao, L., Jiang, L. and Xin, Q. (2007) Comparison of Different Promotion Effect of PtRu/C and PtSn/C Electrocatalysts for Ethanol Electro-Oxidation. Electrochimica Acta, 52, 6622-6629. http://dx.doi.org/10.1016/j.electacta.2007.04.056

[29] Gupta, S.S. and Datta, J. (2006) A Comparative Study on Ethanol Oxidation Behavior at Pt and PtRh Electrodeposits. Journal of Electroanalytical Chemistry, 594, 65-72. http://dx.doi.org/10.1016/j.jelechem.2006.05.022

[30] Feng, Y., Liu, Z., Kong, W., Yin, Q. and Du, L. (2014) Promotion of Palladium Catalysis by Silver for Ethanol Electro-Oxidation in Alkaline Electrolyte. International Journal of Hydrogen Energy, 39, 2497-2504. http://dx.doi.org/10.1016/j.ijhydene.2013.12.004 